\title{
Do or die? The UK, the EU, and internal/external security cooperation after Brexit
}

\author{
Simon Sweeney ${ }^{1} \cdot$ Neil Winn $^{2}$
}

Accepted: 11 January 2021 / Published online: 2 March 2021

(c) European Consortium for Political Research 2021

\begin{abstract}
The European Union (EU) integration project is under attack from a reassertion of national sovereignty following Brexit and the Covid-19 crisis. Our analysis examines the impact that traditional forms of sovereignty and national interests will have on the conduct of EU foreign and security policy post-Brexit. We focus on the Brexit challenge to the EU mode of regulation and diplomacy in internal/external policies in Common Foreign and Security Policy, Common Security and Defence Policy, and Justice and Home Affairs. The article also considers key scenarios for future UK-EU security cooperation to inform analysis of likely policy outcomes for the UK and the EU. The article concludes that the EU will have a greater impact through its laws and regulations on the post-Brexit UK than vice versa and that Brexit is not an immediate threat to the EU's regulatory mode of security governance. The new realities of internal/external security governance in Europe post-Brexit will mean weakened EU-UK security arrangements, which will impact the scope and quality of European security cooperation beyond traditional defence. This is both undesirable and potentially dangerous for European security cooperation and for Europe's position in the wider world.
\end{abstract}

Keywords Brexit · CSDP · European Union · Justice and home affairs · Security cooperation $\cdot$ Sovereignty

Simon Sweeney

simon.sweeney@york.ac.uk

Neil Winn

n.winn@leeds.ac.uk

1 Management School, University of York, Heslington, York YO10 5GD, UK

2 School of Politics and International Studies, University of Leeds, Leeds, UK 


\section{Introduction}

Since the United Kingdom referendum on EU membership in June 2016 much of the legal and political science/international relations literature has focused on how the UK can remain linked to the EU in internal and external security terms, and on postBrexit EU external relations. ${ }^{1}$ This paper examines the external relations regime of the EU, and UK/EU relations in terms of internal/external security policy. The UK's separation from the jurisdiction of the EU Court of Justice (EUCJ) renders the UK a third country beyond EU governance. The EU-UK Trade and Cooperation Agreement (TCA) of 24 December 2020 does not cover security/defence, and determining this relationship is for the future (HM Government 2020).

Recent EU-UK security cooperation has been managed on an ad hoc case-bycase basis. The UK can pick and choose when to cooperate on pressing issues such as Libya, Covid-19, Iran, and climate change. This is at odds with the EU's structured approach to foreign and security cooperation. London balks at notions of EU strategic autonomy (Macron 2020; Borrell 2020a, b) as a potential threat to NATO, as well as perceived French unilateralism in foreign and security policy. Finally, the declaratory nature of much EU foreign policy is not attractive to London.

The EU supports a rules-based international order (Bradford 2012, 2020). It sets new agendas, standards, and rules as a "norm promoter". It appears as a consistent internationalist in a world shifting towards populism, and localism (Fahey 2020). The Union has applied these same principles to negotiations with the UK.

EU officials responsible for negotiating the UK's departure from the Union, under direction from member state governments, maintained that the UK should not achieve advantages from leaving, exposing the UK's ambition to achieve "frictionless" trade with the Union while freeing itself from single market legislation and EUCJ jurisdiction (May 2017; Tocci 2018). The UK approach was pilloried as a "cake" policy, having while eating (Tusk 2016; Stojanovic 2017). Supporters of Leave in the UK emphasised Britain's role as a diplomatic and foreign policy power, deploying the aspirational phrase "Global Britain" (May 2017). This puts a Eurosceptic twist on a long-standing UK grand strategy involving global leadership in which "Europe" always played an ambiguous part (Daddow 2019). They stress Britain's past imperial power and status as head of the Commonwealth and its permanent 5 status in the UN Security Council (UNSC). For many, the referendum was a demand to reassert British sovereignty across multiple policy domains. Arguably, the UK's global status may be damaged by Brexit but losing an economy the size of the UK with its considerable reach through diplomatic networks damages the EU too (Martill and Sus 2018). London's foreign policy has been distinctly ideological and remains so, even in the context of an Integrated Review of Security, Defence, Development and Foreign Policy (UK Ministry of Defence 2020). There may also be a lack of mutual trust between the UK government and its counterparts in

\footnotetext{
${ }^{1}$ For an overview of various state-of-the-art literatures associated with Brexit, see Richardson, J. and Rittberger, V. (2020) (eds) 'The Brexit Policy Fiasco'. Special Issue, Journal of European Public Policy. 27(5): 649-794.
} 
Brussels, a potentially serious issue going forward. Various possibilities for security cooperation include bilateralism, the multilateral NATO route, and forms of issuespecific cooperation, but all will prove inferior to structured arrangements within the EU framework (Balfour 2020).

In the following sections, we focus on how Brexit challenges the EU model of regulation and diplomacy in CFSP and CSDP, and in Justice and Home Affairs (JHA) where this concerns security cooperation across state borders. We hypothesise that Brexit challenges the EU model of supranational regulation and diplomacy across the full range of external policy making. We also hypothesise that the watered-down EU-UK security relationship will mean worse outcomes for both parties. Finally, we assess the implications for the Union in security terms, a key issue for post-Brexit EU-UK relations.

Intergovernmentalism in the EU has increased in recent years. The Union has failed to speak with one voice on global security challenges, including internal/ external threats, nationalism/populism in Hungary and Poland, and on Covid-19. However, its united front during the Brexit negotiations frustrated British attempts to conduct bilateral discussions with key member states, especially under Theresa May's leadership (Figueira and Martill 2020). While Brexit asserts a traditional view of sovereignty, the Union displays tensions between intergovernmentalism and common policy. Aside from the single market and the common front on Brexit, intergovernmentalism has been in the ascendance. Several member states opposed quotas on the distribution of migrants following the 2015 migration crisis (Juncker 2015; Zalan 2016). Poland and Hungary resisted Commission pressure regarding values, law, and justice, even delaying approval for the 2021-27 multiannual budget (Bayer 2020; European Council 2020a). They also led Visegrad resistance to an overhaul of migration and asylum rules (France24 2020; Reuters 2020). More recently, the EU response to Covid-19 has been described as "too slow" and "fragmented", with member states adopting contrasting measures to address the crisis (Banks 2020, 2021).

The UK leaving the Union is consistent with this intergovernmental trend, and it challenges European integration. Brexit is in the vanguard of the intergovernmental and global security challenges that both the UK and the EU face. It is also essential to analyse future EU-UK security cooperation scenarios, given the centrality of this relationship to Europe's stability.

\section{Brexit and the common foreign and security policy (CFSP) and common security and defence policy (CSDP)}

How will Brexit affect this policy field? The implications for the Union are striking given that France and the UK are the only member states with "full-spectrum" power projection capability and strategic cultures that tolerate military intervention and the use of fire power (IISS 2019; Mölling and Giegerich 2018). Both are P5 UN Security Council members and nuclear powers. They constitute around 25 per cent of EU defence expenditure, the UK slightly ahead of France 
(Stojanovic 2017). So, the potential loss in military capability implied by Brexit is substantial. If CSDP has aspired to enhance EU defence capability, then Brexit undermines this ambition.

The Commission also indicated that by statute, UK contractors could not bid for contracts concerning the encrypted military components of the Galileo Satellite project, whereupon London indicated it would build its own system (Gannon 2018). The government contemplated a low orbit alternative to Galileo (Hollinger and Parker 2020), but later abandoned this for technical reasons, and on cost grounds following the coronavirus pandemic (Gallardo 2020). Without its own alternative, London would need to pay for access to Galileo's military encryption or pay the USA to use GPS.

Arguments over Galileo highlight how despite warm words about cooperation, Brexit shakes the structure of UK involvement in EU security and defence. Brexit may have little impact on the UK military, but it deprives the UK of influence over the EU's CSDP (UK Parliament 2016). Another report highlights risks from the UK losing access to EU defence projects and to the European Defence Fund (Institute for Government 2020). Another sign of declining British influence is that command of the CSDP counter piracy operation off Somalia moved from near London to Rota in Andalusia (TRT World 2018; EU NAVFOR Atalanta, 2021).

On the plus side, the UK is a key NATO member, one of the few European states spending two per cent of GDP on defence. Now, prospects for continued UK commitment to European defence and security revolve around three possible scenarios: $\mathrm{CSDP}+$, NATO, or strengthened bilateral ties, especially with France (Martill and Sus 2018). There seems little prospect of the UK disengaging altogether: the EU and especially France, but also the UK, have emphasised their common interests in a close defence and security relationship. While in theory the UK could continue to contribute to CSDP, this is unlikely because as a third country it would have no planning, decision-making, or leadership role.

Brexit may present the EU with opportunities as well as threats. The EU Global Strategy (EEAS 2016) set new ambitions for EU actorness in foreign and security policy. The Commission's European Defence Action Plan was an early sign of it seeking to promote common defence and a more competitive European defence equipment market (European Commission 2016). The UK took a backseat as several initiatives followed, some which London would have resisted (Tocci 2018; Anghel and Fogel 2018). These included the launch of Permanent Structured Cooperation (PESCO). Next, in 2017 the Commission launched the European Defence Fund (EDF) with $€ 600$ million annually until 2020 and $€ 7.9$ billion thereafter to support collaborative spending by groups of member states (Kelly 2021). This contribution is not insignificant, but nor is it transformative, especially as the EDF allocation underwent a 40 per cent cut due to the coronavirus pandemic (Quintin 2020). A European Parliament study cautions that benefits from the EDF are likely to be small, as states remain wedded to domestic suppliers in purchasing and investment (Wilkinson 2020). A third step was the Council-initiated Coordinated Annual Review on Defence (CARD), backed by the EDA secretariat. CARD monitors member state defence spending and identifies opportunities for pooling resources and building joint capabilities. It attempts to build on ten years of EDA efforts towards a 
coordinated approach to capability development, with pooling and sharing between member states, and cooperative research and technology (R\&T).

What has been lacking (...) is a high-level coordination format with a specific forward-looking capability-oriented mandate, giving the central role to member states, who finance and implement this political guidance through their national processes. The CARD, conceived as a monitoring mechanism driven by member states, can very effectively fill that gap (van Raybroeck 2019).

With proper member state support, PESCO and CARD could constitute integrative steps towards defence capability. But among 47 joint projects, none were big-ticket strategic enablers, such as the new Airbus Defence and Space FCAS under development outside of the PESCO framework, involving France, Germany, and Spain (Hoyle 2019; Sprenger 2020; Besch 2020). Moreover, Brexit threatens the viability of a unified European Defence and Technological Industrial Base (EDTIB), especially since the UK's BAE Systems, with Swedish, Italian, and possibly Dutch partners, is developing a rival to the Airbus project. Ominously, an EDA official doubted the viability of two competing air combat projects (Euroactiv 2019).

British engagement through PESCO or CSDP could imply a sovereignty cost for the UK since it would lack participation in decision-making. In contrast, UK commitment to NATO represents continuity and is barely impacted by Brexit, with the Art.5 commitment unaltered (NATO 1949).

As well as NATO, the other continuity channel for UK engagement in European security and defence is bilateral cooperation with France. Since the 2010 Lancaster House agreements, the two leading powers in Europe have developed a closer military relationship, including the Combined Joint Expeditionary Force (CJEF) (UK Ministry of Defence 2016, 2010). Neither engagement through NATO nor bilateral agreements run into the sovereignty challenges that arise with EU-led initiatives. An important caveat: security cooperation with France or the EU may be undermined by deterioration in UK-EU relations post-Brexit (Taylor 2020). Difficult trade negotiations regarding services, or border disputes, or "level playing field" concerns regarding the EU single market, could degrade trust and cooperation in security and defence. The same applies for security around migration, policing, counter terrorism, and data sharing (see below).

Additionally, UK sovereigntists should not assume that their partners in Paris are focused only on cross-channel ties. France and Germany updated their 1963 Elysée Treaty of Friendship in 2019 at Aachen, strengthening mutual defence commitments between Paris and Berlin, beyond those in NATO Art.5 or TEU Art.42.7 (Perot 2019). This format is further explored through the E3 involving the UK, France, and Germany, thus helping to bind London to the larger EU powers (Billon-Galland and Whitman 2020). There could be concerns over Italy, Spain, and Poland feeling left out of E3 arrangements. In the absence of deeper or wider cooperation within the EU, and involving the UK, the E3 framework might work well.

The UK seems unlikely to seek participation in PESCO and will be ineligible for EDF support. In the interests of strengthening European defence, EU27 might welcome British involvement, but ironically, if the UK were still in the EU, the traditional unanimity requirement could have stymied such initiatives. Another 2017 
innovation was the Military Planning and Conduct Capability (MPCC), a command centre in Brussels for the military aspects of civilian crisis management. This would have been condemned in Britain as a step towards an "EU Army". Next, in 2018, the Commission launched the European Defence Industrial Development Programme (EDIDP), a preparatory step before the onset of the EDF in 2021. It is designed to promote multinational industrial $R \& D$ projects that can assist European strategic autonomy, so reducing reliance on the USA. It should also promote EU-NATO collaboration (Euroactiv 2018; European Council 2018). The EU might also develop the concept of multinational brigades, with or without UK participation (Biscop 2020a).

A further indication of deeper Commission involvement in EU defence was the creation of a separate Directorate General, DG Defence Industry and Space in the Ursula von der Leyen Commission. The remit of DG DEFIS encompasses EDF oversight, promotion of an open and competitive defence equipment market and compliance with defence procurement rules, an Action Plan on Military Mobility, fostering an innovative EU space industry, and implementation of the EU Space Programme including development of Galileo (Gotkowska 2019). UK absence from these endeavours will have damaging consequences for the Union and Britain. The exclusion of UK technological and industrial capability from EU defence-industrial projects represents mutual disadvantage (Taylor 2020).

None of these developments alter the fundamental intergovernmental nature of CSDP (Donnelly 2010; Martill and Sus 2018). Brexit may potentially prompt moves towards qualified majority voting (QMV) in CFSP. This has a clear logic in an EU of 25 or more members (Blockmans 2017). Nevertheless, PESCO offers an opportunity since it is underpinned by the legal force of a Council directive and came not from the Commission, but from a joint undertaking by France and Germany. To be effective, PESCO must prioritise strategic enablers that bring real defence capability, and it must work towards creating integrated forces under multinational frameworks (Biscop 2017, 2018). PESCO critics complain that under pressure from Germany, instead of enabling smaller groups of states to advance projects, it mutated into a 25-member state instrument that requires consensus (Nováky 2018). This restricts capability development and risks free riding (Witney 2017). PESCO is supposed to involve effective compliance monitoring through a form of convergence criteria, a function that CARD could supply, but only if the process is mandatory, not optional (Biscop 2017). Finally, PESCO, and European defence generally, needs money which states are perennially reluctant to supply (Sus 2017), more so since Covid-19. Ironically, the more effective PESCO is, and the more it involves CARDled monitoring, the less likely is UK involvement. PESCO's legal basis is also a substantial impediment to third country participation.

The UK is a key military and diplomatic actor, but Brexit undermines UK foreign and defence policy influence. A new bilateralism between the UK and EU partners will likely become the new normal, in the absence of deeper institutional relationships within EU frameworks. Bilateral relationships with France and Germany will be key for the UK. Nevertheless, one cannot separate these relationships from the broader contexts within which such cooperation exists (Pannier 2020). A more multilaterally inclined USA under President Biden will provide 
an overarching mechanism for bi- and tri-lateral security cooperation between London, Paris, and Berlin. The UK position as Washington's gateway to the EU regarding security has gone, and the favoured interlocutors now are Berlin and Paris. Where defence and intelligence are concerned, the UK will remain America's most important ally in Europe, as well as internationally.

Bilateral security cooperation between Britain and France will continue within the UN system, but Paris also coordinates policy with the EU. In theory, this could help cooperation between Britain and the EU in the UN. The UK remains a permanent member of the UNSC, even though its influence may be declining, partly due to Brexit (Gifkins et al 2019).

The UK's position in NATO remains highly significant. We may expect London to use the Atlantic Alliance as a key supplement to bilateral defence and security relationships with Washington, Berlin, Paris, Rome, Madrid, and Warsaw. The UK remains the leading European military power, but anticipated economic decline may inhibit London's capacity to maintain its current defence posture (Goodman and Meakin, 2020; Tetlow and Pope, 2020). The UK economy faces decline relative to upcoming powers such as India, Brazil, and China (Sampson 2020). The UK could become less relevant to American grand strategy, but Brexit makes NATO even more important to UK foreign and defence policy, as well as to transatlantic security (Cladi and Locatelli 2020).

The UK also remains a leading member of the Commonwealth, though again this is arguably a declining relationship, as the UK loses influence and new relationships form for countries with new agendas beyond Britain (Clegg 2016). UK influence in other international institutions such as the World Bank, IMF, and WTO is also declining (Roberts et al 2019), as evidenced by London's failure to get Liam Fox appointed head of the WTO in 2020.

Within broader CFSP frameworks, Brexit could provide opportunities if London manages to carve out a niche as an independent influencer. Niblett (2021: 1) suggests "a blueprint for Britain's future foreign policy". To succeed, Britain needs to focus less on great power ambitions, but more on developing influence as a broker of solutions. Priorities should be protecting liberal democracy, promoting peace and prosperity, tackling climate change, championing global tax transparency and equitable economic growth, and defending cyberspace (ibid). Crucially, however, London's partnership with the EU is of primary importance in achieving these objectives, even ahead of the USA, and significantly ahead of identified targets of the "Global Britain" agenda, such as China, India, Saudi Arabia, and Turkey. We argue that EU membership was no barrier to Britain pursuing these objectives. Indeed, UK influence is probably less now than as a member state.

Tonra (2019) highlights possible directions for future EU-UK defence and security cooperation. The EU has identified two key scenarios. The first involves the loss of formal defence, security, and foreign policy cooperation, and instead using bilateral arrangements through NATO and the OSCE. This approach risks destabilising the EU-NATO relationship. The second involves tailored issue-by-issue bilateral relations, including participation in CSDP and CFSP. This is legally challenging and could be politically unacceptable in Britain. 
Tonra argues that possible UK choices for defence and security cooperation with the EU are more complex and relate to domestic political exigencies. He suggests four scenarios. (i) The UK playing a special global role in security, a "decentring of UK foreign policy away from a European to a greater global perspective", (ibid, 234). (ii) The UK as an Atlanticist mini-hegemon, with NATO central to defence policy. This could engender tensions in EU-NATO relations. (iii) The UK intensifying defence cooperation in Europe but from outside the EU, using mini-lateral and bilateral frameworks in pursuit of European defence and security interests, for example reinforcing the France-UK Lancaster House treaties and creating similar arrangements with Germany and Poland, or enhancing President Macron's European Intervention Initiative (EI2) (Macron 2017; Nováky 2018). (iv) A unique UK-EU partnership that maintains UK decision-making within CFSP and CSDP, and participation in ministerial meetings. This has been firmly rejected by the EU.

In summary, Brexit presents important security and defence challenges to both the EU and the UK. The institutional innovations following Britain's referendum in 2016 (PESCO, EDF, CARD, MPCC, EDIDP) constitute opportunities for coordinated multilateral projects that could deliver capability enhancement. "EU integration (in security and defence) has been consolidated and advanced in response to Brexit" (Jokela 2020: 114). This integration might be better described as cooperation, but it does suggest more understanding of common interests. Greater harmonisation around CFSP/CSDP should follow (Martill and Sus 2018). Integration will remain limited if member states persist with the intergovernmentalism traditionally dominant in CFSP. Moreover, the coronavirus pandemic risks undermining member states' focus on consolidation, pooling and sharing, and commitment to joint projects in defence-related manufacturing and capability enhancement (Quintin 2020; Biscop 2020b).

For the UK, the continuity route is cooperation through NATO and bilateral (nonEU-mediated) agreements with France and the Nordic or northern European countries. Closer French-British ties through the European Intervention Initiative (EI2) could build on the Lancaster House treaties, and the CJEF. The UK is also the protagonist in another Joint Expeditionary Force (JEF) involving the Nordic and Baltic States, and the Netherlands (UK Ministry of Defence 2014). ${ }^{2}$ The scope for UK participation in EU instruments looks limited, or available at a cost in terms of sovereignty, for example UK participation in CSDP with no role in decision-making, and without meaningful participation in the Political and Security Committee which oversees CSDP.

In a broader strategic sense, Larik (2018) argues that Brexit and Trump represent upheaval while the EU Global Strategy seeks to guard the liberal world order against populisms on both sides of the Atlantic by defending outward-looking cosmopolitan and multilateral values. Joe Biden's election to the US Presidency signals more traditional forms of liberal internationalism and multilateralism, and a push back against populism and normative backsliding. The British role in EU security policy

\footnotetext{
2 In June 2017, Sweden and Finland joined the JEF. Founder members of this UK initiative were Denmark, Estonia, Latvia, Lithuania, Netherlands, and Norway.
} 
is diminished by Brexit, as the UK loses voting rights and veto in CFSP/CSDP. Both parties will be militarily weakened. More broadly, a key question for British foreign and security policy outside the EU is to what extent will a Biden administration relegate the UK to a lower status than Germany and France in bilateral relations with European states?

\section{Brexit and justice and home affairs}

Justice and Home Affairs (JHA) is located within the EU Area of Freedom, Security and Justice (AFSJ). Internal and external security agendas in the EU are inextricably linked, with AFSJ-CFSP ties substantially upgraded in recent years (Bossong and Lavenex 2016; Carrapico and Farrand 2020). Brexit, however, is likely to be disruptive. The EU Global Strategy emphasises internal security given that external security is increasingly instrumentalised to achieve AFSJ objectives (Carrapico et al 2019).

The Amsterdam Treaty created the AFSJ, bringing several security-related competences, including the Schengen acquis, into Community affairs under EU Court of Justice jurisdiction. AFSJ displays increasing cross-over into CFSP and external security, as the internal/external security distinction has become blurred. This is evident in border security, asylum, migration, combatting organised crime, policing and judicial matters, and cybersecurity. Creating an internal security strategy extends into external policy, so the AFSJ moves justice and home affairs closer to CFSP and CSDP. The development and human rights interests of CSDP attempt to reduce migratory flows into Europe. This blurring between internal and external security reflects a need for more common policy and a more integrated CFSP (Monar 2010), and deeper cooperation between the Commission and the High Representative for Foreign Affairs and Security Policy (Carrapico and Farrand 2020).

Brexit is likely to significantly affect JHA, since several decades of internal security integration have created "a complex network of cooperation" between EU and UK security structures (Carrapico et al 2019: 5). A likely tension in EU-UK relations concerns respective willingness to limit social media platforms, where EU interest in combatting harmful propaganda is perceived as a lesser concern for the more libertarian UK (Carrapico and Ferrand 2020). More broadly, cooperation on policing and security, including cybersecurity, will be critical in a new EU-UK relationship. The UK leaving the EU legal framework and its policing and judicial agencies, Europol and Eurojust, and falling outside the European Arrest Warrant (EAW), will have major bi-directional implications in the fight against organised crime and terrorism. Any limitation on shared access to databases holding criminal records, DNA, Passenger Name Records, and fingerprinting data will seriously undermine policing and security (ibid 15-40). The TCA does allow security-related data exchange, but not UK real-time access to the Schengen Information System (SIS II). According to The Economist (2018) "Britain's police forces searched for criminal records on the Schengen Information System 539 m times (in 2017)”. The UK dropped out of the European Arrest Warrant and is seeking an alternative extradition mechanism. Britain requested 2,741 arrests in other EU countries while receiving 
14,553 requests from EU member states in the fiscal year 2019-20 (National Crime Agency 2021).

The European Council adopted the Prüm Decisions concerning DNA-data sharing, finger printing, and vehicle registration records in August 2008, although its full implementation throughout all member states took several years, with most applied by 2017 (European Council 2020b). On 31 December 2020, the UK lost 40,000 alerts derived from EU data bases. The UK National Crime Agency has lamented that British police will no longer have access to Europol or the SIS II data base, which contains sensitive information on organised criminals. UK authorities lose access to EU-wide criminal intelligence and will rely on potentially less reliable bilateral relationships, and on Interpol (BBC News 2020).

Sharing databases became controversial during 2019-20 with the UK accused of misusing EU data through unlawful sharing with the USA, and not sharing data on 75,000 convicted criminals with their home countries (Boffey and Beckford 2020a, 2020b). Mistrust was compounded in 2020 by London insisting on continued access to SIS and Europol despite these being restricted to EU member states and under EU Court of Justice jurisdiction (Oltermann and Boffey 2020). The UK's position contradicts London's insistence that it could not be accountable to the EUCJ.

Cybercrime is another area where Brexit undermines both UK and European security. Reduced access to shared databases, impaired police and intelligence cooperation, and diminished joint research initiatives carry negative implications for both parties (Lavorgna 2019). The UK has been a leader in cybersecurity at the EU level (Wall 2016). There has been an EU-wide trend towards increasingly close networks of information and intelligence sharing, essential in combatting serious organised crime including child exploitation, trafficking, money laundering, and IT systems hacking. Inevitably, the UK loses influence and access to transnational cooperation, damaging transnational efforts to combat cybercrime (Hillebrand 2017).

Without full access to Europol, the EAW, and SIS II, London, no longer benefits from EU instruments developed over several decades. Replicating these structures will be costly and inefficient, perhaps completely implausible. Observer status within Europol or Eurojust is a poor substitute for membership. A former EU counter terrorism coordinator commented that police and judicial cooperation will become "more cumbersome, messy, and even a predictable source of acrimony. Britain will trade security for the semblance of sovereignty" (de Vries 2019). A former head of MI5 insisted that close ties with Europol was "absolutely vital" to UK security, especially in combatting terrorism (Dearden 2019).

Finally, a further potential Brexit-related security problem for both the UK and the EU is the Northern Ireland/Ireland border. The 2019 Withdrawal Agreement (WA) avoids the need for a "hard border" on the island of Ireland by mandating checks on goods passing between Great Britain and Northern Ireland-a "border in the Irish Sea". This arrangement is widely regarded as essential to upholding the 1998 Good Friday Agreement (GFA). It avoids Ireland/Northern Ireland border checks. The WA and the TCA effectively keep Northern Ireland within the EU single market, but the working partnership between Dublin, London, and Belfast contained in the GFA will face new, and potentially severe, tests. Combatting crossborder smuggling is an issue that will require close partnership and coordination, 
but this cannot be guaranteed given the complications inherent in the UK being outside the EU.

Border security is not simply a trade matter: "the peace in Northern Ireland remains fragile" (Keohane 2020). Almost half (56) of 119 terrorist attacks in the EU in 2019 were "ethno-nationalist" or "separatist", and of these all but one involved dissident Irish republican groups in Northern Ireland (Europol 2020: 16). Europol describes the threat from dissident Republicans as "severe" (ibid 54).

In summary, various scenarios exist for UK-AFSJ relations. In criminal justice matters, the UK becomes a third country, and this will inevitably diminish UK-EU cooperation compared to the UK as an EU member state. The UK was not a member of Schengen, and EU-UK free movement of people ended on 31 December 2020. Additionally, the UK has reduced access to Europol criminal databases, and impaired transfer of criminal justice information between the UK and EU law enforcement agencies. Regarding data protection, it remains to be seen if the UK will meet EU data adequacy tests and the extent to which the EUCJ will continue to rule in areas related to UK-EU data protection.

\section{Conclusion}

We have examined the impact on UK and EU external and internal security policy resulting from the UK's departure from the European Union on 31 January 2020, albeit with a "no change" transition period to the end of the year. With the end of transition, we argue that in all aspects of security, external and internal, both parties suffer from less intensive cooperation, but the risks for the UK seem greater. Despite being a permanent member of the UNSC, a nuclear power, and head of the Commonwealth, the UK will experience a loss of international influence. Britain is relinquishing its role as a leading shaper of the EU single market and loses voting rights and veto in the CFSP and CSDP. It faces exclusion from EU defence structures, including PESCO and the EDF, the European Defence Agency and the militarystrategic components of the Galileo satellite system. Britain has been Washington's foremost European interlocutor, but even that role looks in jeopardy post-Brexit. On security, France could become Washington's key European channel while Germany will dominate transatlantic trading relations (Barichella 2016). The durability of the UK's much vaunted "special relationship" with the USA should not be taken for granted, since one of its major purposes from a US perspective was to better understand the direction of EU policy. This is compromised by Brexit (The Economist 2020). Nevertheless, Washington will continue to value highly a comprehensive bilateral relationship with London, including the defence and intelligence sectors.

The UK is unlikely to benefit from any purported sovereignty gain as a non-member of the EU. In a multipolar international political economy, trade blocs and large states wield the most influence in international forums like the WTO, or in combatting global challenges like climate change, pandemics, and international terrorism. While in some areas the London government appears to support multilateral institutions, in others it seems less interested, and quitting the European Union is considered questionable and even regrettable by various governments and observers 
outside Europe (Yu 2017; Oliver 2016; UK Parliament 2019; The Observer 2019; Ring et al 2018).

Liberal internationalism is still the dominant means of organising international relations between Western actors in the international system, but this has come under pressure with the rise of populism, right-wing extremism and new nationalisms in Europe and the USA. The election of President Biden will likely reverse some of these trends, at least temporarily. But populist pressures in Europe may yet challenge the EU's dominant mode of elite regulatory governance as well as the fundamental tenets of the European integration project as it has evolved since the early 1950s. Brexit is the most high-profile countermovement but is unlikely to alter the basics of the EU or its integration, despite warnings that "the European Union must take very seriously the need for democratic and social reform and renewal" (de Búrca 2018). Indeed, member states' united response to Brexit may reinforce the foundations of the integration process (Schimmelfennig 2018).

The evolving coronavirus pandemic places further strains on the $\mathrm{EU}$, on the integrity of the single currency and Eurozone. But a crisis of this magnitude further underlines the need for EU solidarity and common responses to challenges across all policy fields, including CFSP (Biscop 2020b).

Covid-19 will surely disrupt EU security planning and may marginalise CSDP due to funding constraints, including the reduced EDF allocation (Quintin 2020). The economic fall-out from the pandemic will squeeze member states' commitment to CSDP, and political attention will focus on broader recovery objectives. But the pandemic also strengthens the case for EU defence on geopolitical and economic grounds (Billon-Galland 2020; Biscop 2020b). Despite competing claims from the Green New Deal, agriculture, and the regions, "the EU should not completely abandon its pre-Covid-19 security and defence agenda" (Nováky 2020). The pandemic does not eliminate the need for a strategic and capable EU security and defence policy, but it makes achieving that goal more difficult. As the UK transitions to post-Brexit foreign and security policy arrangements with the EU, attitude to policies is key: worryingly, the UK government's apparent lack of concern over reduced cooperation in security and policing may be a sign of how defence could be treated (Taylor 2020). This might seem negative in tone, but indifference should be avoided at all costs if there are to be positive prospects for EU-UK defence and security cooperation.

The UK's descent from power after 1945 is one of relative decline (Hill 2019). National foreign policy came to rest on the two pillars of the Atlantic alliance and the EU Common Foreign and Security Policy. With Brexit, the UK becomes a third country to the EU and its member states. Geography, history, and limited resources mean that Britain will continue to have a foreign policy partnership with the member states of the Union (ibid). Niblett (2021) argues that despite Brexit, the UK's working relationship with the EU will be fundamental to the conduct of foreign policy as both share similar values and interests, echoing The Economist newspaper (The Economist 2021).

The EU remains an important player in the global political economy and one with considerable normative influence on other regions of the world. Indeed, the rules and regulations originating from Brussels have penetrated many aspects of 
economic life within and outside of Europe through the process of "unilateral regulatory globalization" (Bradford 2012: 3, 2020). This occurs when a single state (or state-like entity) "is able to externalize its laws and regulations outside its borders through market mechanisms, resulting in the globalization of standards" (Bradford 2012: 3). Following this logic, the EU will have a far greater impact through its laws and regulations on the post-Brexit UK than vice versa.

In the final analysis, Brexit will impact negatively on EU-UK security cooperation and damage the quality and scope of European security. This is both worrying and potentially dangerous. Fragmented cooperation sends a message to the outside world that Europe is internally divided. This can only give succour to those wishing to undermine EU and broader security cooperation in Europe.

\section{References}

Anghel, S.E. and Fogel, B. 2018. 'The European Council's 'rolling agenda' on European Defence Cooperation' Briefing. European Council in Action. European Council Oversight Unit. Brussels: European Parliament. http://www.europarl.europa.eu/RegData/etudes/BRIE/2018/621832/EPRS_ BRI(2018)621832_EN.pdf. Accessed 27 January 2021.

Balfour, R. 2020. 'After Brexit: Recasting a UK-EU dialogue on foreign policy', Foreign Policy Centre Policy Paper. https://fpc.org.uk/after-brexit-recasting-a-uk-eu-dialogue-on-foreign-policy/. Accessed 27 January 2021

Banks, M. 2020. 'Von der Leyen apologises for EU's initial lack of coronavirus preparedness' The Parliament Magazine. 16 April. https://www.theparliamentmagazine.eu/news/article/von-der-leyen-apolo gises-for-eus-initial-lack-of-coronavirus-preparedness. Accessed 27 January 2021.

Banks, M. 2021. 'European Commission defends Coronavirus vaccine strategy following fierce criticism that vaccination roll out has been too slow' The Parliament Magazine. 7 January. https://www. theparliamentmagazine.eu/news/article/the-european-commission-has-made-a-robust-defence-ofits-coronavirus-vaccine-strategy-following-fierce-criticism-that-vaccination-roll-out-has-been-tooslow. Accessed 27 January 2021.

Barichella, A. 2016. 'Transatlantic relations after Brexit', European Issues 409. 30 October. Robert Schuman Foundation. https://www.robert-schuman.eu/en/european-issues/0409-transatlantic-relationsafter-brexit. Accessed 27 January 2021.

Bayer, L. 2020. EU budget plan lets Hungary, Poland off the rule-of-law hook (for now) Politico. 9 December. https://www.politico.eu/article/eu-budget-plan-lets-hungary-poland-off-the-rule-of-lawhook-for-now/. Accessed 27 January 2021.

BBC News. 2020. 'Brexit: UK police to lose access to crime fighting tools. https://www.bbc.co.uk/news/ amp/uk-politics-55351598. 17/12/20. Accessed 27 January 2021.

Besch, S. 2020. 'EU's Institutional framework regarding Defence Matters' in 10 Years of CSDP: Four in-depth analyses requested by the sub-committee on Security and Defence of the European Parliament. Brussels: European Parliament. https://www.europarl.europa.eu/thinktank/en/document. html?reference=EXPO_IDA(2020)603485. Accessed 27 January 2021.

Billon-Galland, A. 2020. 'COVID-19 Strengthens the Case for EU Defence' Expert Comment. 17 June. London: Chatham House. https://www.chathamhouse.org/2020/06/covid-19-strengthens-case-eudefence. Accessed 27 January 2021.

Billon-Galland, A. and Whitman, R. 2020. E3 Cooperation beyond Brexit: Challenging but Necessary. 2 September. Chatham House. https://www.chathamhouse.org/2020/09/e3-cooperation-beyond-brexi t-challenging-necessary. Accessed 27 January 2021.

Biscop, S. 2020a. Battalions to brigades: the future of european defence. Survival 62 (5): 105-118. https ://doi.org/10.1080/00396338.2020.1819654Accessed27January.

Biscop, S. 2020b. No peace from corona: defining EU strategy for the 2020s. Journal of European Integration 42 (8): 1009-1023.

Biscop, S. 2017. 'European defence: What's in the CARDs for PESCO?' Security Policy Brief 91 October. Brussels: Egmont Institute. 
Biscop, S. 2018. European Defence: Give PESCO a chance. Survival 60 (3): 161-180.

Blockmans, S. 2017. Differentiation in CFSP: Potential and Limits. Rome: IAI.

Boffey, D. and Beckford, M. 2020a. 'UK accused of 'behaving like cowboys' over EU database copying' Guardian, 9 January. https://www.theguardian.com/world/2020/jan/09/uk-accused-of-behavinglike-cowboys-over-eu-database-copying. Accessed 27 January 2021.

Boffey, D. and Beckford, M. 2020b. ‘Britain could lose access to EU data after series of scandals' Guardian, 27 January. https:/www.theguardian.com/politics/2020/jan/27/britain-could-lose-access-toeu-data-after-series-of-scandals\#img-1. Accessed 27 January 2021.

Borrell, J. 2020a. Foreign Affairs Council: Remarks by the High Representative/Vice-President at the press conference. 7 December. https://eeas.europa.eu/headquarters/headquarters-homepage/90039 /foreign-affairs-council-remarks-high-representativevice-president-josep-borrell-press_en. Accessed 27 January 2021.

Borrell, J. 2020b. 'Why European Strategic Autonomy Matters' Blog. 3 December. European External Action Service. Brussels: EEAS. https://eeas.europa.eu/headquarters/headquarters-homep age/89865/why-european-strategic-autonomy-matters_en. Accessed 27 January 2021.

Bossong R. and Lavenex, S. 2016. 'Governance and EU Internal Security Cooperation', in R. Bossong and M. Rhinard (eds.) Theorizing Internal Security in the European Union, Oxford: Oxford University Press.

Bradford, A. 2012. The Brussels Effect. Northwestern University Law Review 107 (1): 1-67.

Bradford, A. 2020. The Brussels Effect: How the European Union Rules the World. Oxford: Oxford University Press.

Carrapico, H., and B. Ferrand. 2020. Discursive continuity and change in the time of Covid-19: the case of EU cybersecurity policy. Journal of European Integration 42 (8): 1111-1126.

Carrapico, H., A. Niehuss, and C. Berthélémy, eds. 2019. Brexit and Internal Security: Political and Legal Concerns on the Future UK-EU Relationship, 29-30. London: Macmillan.

Cladi, L., and A. Locatelli. 2020. Keep Calm and Carry On (Differently): NATO and CSDP after Brexit. Global Policy 11 (1): 5-14.

Clegg, P. (2016) (ed) Brexit and the Commonwealth: What Next? The Round Table 105(5): 449-596

Daddow, O. 2021. (2019) GlobalBritainTM the discursive construction of Britain's post-Brexit world role. Global Affairs 5 (1): 5-22. https://doi.org/10.1080/23340460.2019.1599297Accessed27Jan uary.

Dearden, L. 2019. ' 'There is no upside' for UK's national security after Brexit, former head of MI5 says'. 30 October. The Independent. https://www.independent.co.uk/news/uk/home-news/brexit-securityintelligence-mi5-terrorism-risk-police-a9178391.html. Accessed 27 January 2021.

de Búrca, G. 2018. Is EU Supranational Governance a Challenge to Liberal Constitutionalism? The University of Chicago Law Review 85 (2): 367.

de Vries, G. 2019. A Hard Brexit will see criminals take back control. In Brexit and Internal Security: Political and Legal Concerns on the Future UK-EU Relationship, ed. H. Carrapico, A. Niehuss, and C. Berthélémy, 87-91. London: Macmillan.

Donnelly, B. 2010. Europe in the World: All Change or No Change in Foreign Policy After Lisbon? The International Spectator 45 (22): 17-22.

EEAS. 2016. 'Shared Vision, Common Action: A Stronger Europe-A Global Strategy for the European Union's Foreign and Security Policy' Brussels: European External Action Service. http://eeas. europa.eu/archives/docs/top_stories/pdf/eugs_review_web.pdf. Accessed 27 January 2021.

EU NAVFOR Atalanta. 2021. EU Naval Force Somalia. Brussels: European External Action Service. https://eunavfor.eu/. Accessed 27 January 2021.

Euroactiv. 2019. 'Europe's fighter jets of the future on collision course?' 28 October. https://www.eurac tiv.com/section/aerospace/news/europes-fighter-jets-of-the-future-on-collision-course/. Accessed 27 January 2021.

Euractiv. 2018. 'MEPs give green light for EU military research fund ahead of NATO summit', 3 July. https://www.euractiv.com/section/defence-and-security/news/meps-give-green-light-for-eu-milit ary-research-fund-ahead-of-nato-summit/. Accessed 27 January 2021.

European Commission. 2016. 'European Defence Action Plan' COM (2016) 950 final. https://eur-lex. europa.eu/legal-content/EN/TXT/?uri=CELEX:52016DC0950. Accessed 27 January 2021.

European Council. 2020a. Multiannual Financial Framework for 2021-2027 adopted. Press Release European Council. Brussels: European Council. https://www.consilium.europa.eu/en/press/press -releases/2020/12/17/multiannual-financial-framework-for-2021-2027-adopted/. Accessed 27 January 2021. 
European Council. 2020b. Stepping up cross-border cooperation (Prüm Decision) Decision 2008/615/ JHA. https://eur-lex.europa.eu/legal-content/EN/TXT/?uri=LEGISSUM\%3Aj10005. Accessed 27 January 2021.

European Council. 2018. European Council Conclusions. Brussels: European Council. https://www.consi lium.europa.eu/en/press/press-releases/2018/06/29/20180628-euco-conclusions-final/. Accessed 27 January 2021.

Europol. 2020. European Union Terrorism Situation and Trend Report 2020. Brussels: European Parliament and Europol. https://www.europol.europa.eu/activities-services/main-reports/european-union -terrorism-situation-and-trend-report-te-sat-2020. Accessed 27 January 2021.

Fahey, E., ed. 2020. Framing Convergence with the Global Legal Order: The EU and the World. London: Hart.

Figueira, F., and B. Martill. 2020. Bounded rationality and the Brexit negotiations: why Britain failed to understand the EU. Journal of European Public Policy 2021. https://doi.org/10.1080/13501 763.2020.1810103Accessed27January.

France24. 2020. 'EU unveils 'compulsory solidarity' plan to share burden of migration' France24, 23 September. https://www.france24.com/en/20200923-eu-to-present-new-plan-on-asylum-seekersaustria-warns-against-mandatory-quotas. Accessed 27 January 2021.

Gannon, M. 2018. 'UK ends Galileo talks, says it will explore a homegrown alternative' 4 December Space News https://spacenews.com/uk-ends-galileo-talks-says-it-will-explore-a-homegrown-alter native/. Accessed 27 January 2021.

Gifkins, J., S. Jarvis, and J. Ralph. 2019. Brexit and the United Nations Security Council: Declining British Influence? International Affairs 95 (6): 1349-1368.

Goodman, D. and Meakin, L. 2020. 'UK economy still faces trade pain after dodging no-deal Brexit' Bloomberg, 24 December. https://www.bloomberg.com/news/articles/2020-12-24/u-k-economystill-faces-trade-pain-after-dodging-no-deal-brexit. Accessed 27 January 2021.

Gotkowska, J. 2019. 'DG for Defence Industry and Space in the new European Commission' 18 September. Analyses. Warszawa: Centre for Eastern Studies (OSW). https://www.osw.waw.pl/en/publi kacje/analyses/2019-09-18/dg-defence-industry-and-space-new-european-commission. Accessed 27 January 2021.

Hill, C. 2019. The Future of British Foreign Policy: Security and Diplomacy in a World after Brexit. Cambridge: Polity Press.

Hillebrand, C. 2017. With or without you: The UK and information and intelligence sharing in the EU. Journal of Intelligence History 16 (2): 91-94.

HM Government. 2020. EU-UK Trade and Cooperation Agreement. 'Trade and cooperation agreement between the European Union and the European Atomic Energy Community, of the one part, and the United Kingdom of Great Britain and Northern Ireland, of the other part'. 24 December 2020.

https://assets.publishing.service.gov.uk/government/uploads/system/uploads/attachment_data/file/94811 9/EU-UK_Trade_and_Cooperation_Agreement_24.12.2020.pdf. Accessed 27 January 2021.

Hollinger, P. and Parker, G. 2020. 'UK scales back plans for rival to £5bn Galileo satellite system' 19 June. Financial Times https://www.ft.com/content/50c3b6dc-2d2f-4bb4-aa9b-b24493315140. Accessed 27 January 2021.

Hoyle, C. 2019. 'Airbus at 50: The future of Airbus Defence \& Space', Flight Global 28 May. https:// www.flightglobal.com/airbus-at-50/the-future-of-airbus-defence-and-space/132620.article. Accessed 27 January 2021.

IISS. 2019. The Military Balance 2019 Paris: International Institute for Strategic Studies. https://www. iiss.org/publications/the-military-balance/the-military-balance-2019. Accessed 27 January 2021.

Institute for Government. 2018. 'UK-EU defence and security cooperation after Brexit'. https://www. instituteforgovernment.org.uk/explainers/uk $\%$ E2\%80\%93eu-defence-and-security-cooperation Accessed 7 January 2021.

Institute for Government. 2020. 'UK-EU future relationship: defence and security cooperation' Explainer. 25 February. https://instituteforgovernment.org.uk/explainers/future-relationship-defence-securitycooperation. Accessed 27 January 2021.

Jokela, J. 2020. 'Strong together? The impact of Brexit on security and defence cooperation' in Towards an ambitious, broad, deep and flexible EU-UK partnership?, 113-118. Brussels: European Political Centre.

Juncker, J-C. 2015. State of the Union 2015: Time for honesty, unity and solidarity, Speech, 9 September. Brussels: European Commission. https://ec.europa.eu/commission/presscorner/detail/en/SPEEC H_15_5614. Accessed 27 January 2021. 
Kelly, É. 2021. 'Brexit treaty offers no easy path to EU defence research funding for UK' 5 January. Science Business. https://sciencebusiness.net/news/brexit-treaty-offers-no-easy-path-eu-defence-resea rch-funding-uk. Accessed 27 January 2021.

Keohane, D. 2020. 'A Terrible Border is reborn? Ireland and a no-deal Brexit' Insight. 25 September. Centre for European Reform. https://www.cer.eu/insights/terrible-border-reborn-ireland-and-nodeal-brexit. Accessed 27 January 2021.

Larik, J. 2018. The EU's Global Strategy, Brexit and 'America First.' European Foreign Affairs Review 23 (3): 343-364.

Lavorgna, A. 2019. Brexit and Cyberspace: Implications for cybersecurity. In Brexit and Internal Security: Political and Legal Concerns on the Future UK-EU Relationship, ed. H. Carrapico, A. Niehuss, and C. Berthélémy, 114-116. London: Macmillan.

Martill, B., and M. Sus. 2018. 'Post-Brexit EU/UK security cooperation: NATO, CSDP+, or "French connection"?' British Journal of Politics and International Relations 20 (4): 846-863. https://doi. org/10.1177/1369148118796979.Accessed27January.

Macron, E. 2020. 'The Macron doctrine: a conversation with the French President' Le Grand Continent 16 November. Groupe d'Études Géopolitiques. https://geopolitique.eu/en/macron-grand -continent/?utm_source=POLITICO.EU\&utm_campaign=c46511c883-EMAIL_CAMPA IGN_2020_11_16_05_58\&utm_medium=email\&utm_term=0_10959edeb5-c46511c883-19017 6737. Accessed 27 January 2021.

Macron, E. 2017. Sorbonne Speech. 26 September. http://international.blogs.ouest-france.fr/archi ve/2017/09/29/macron-sorbonne-verbatim-europe-18583.html. Accessed 27 January 2021.

May, T. 2017. 'The government's negotiating objectives for exiting the EU: PM Speech' 17 January. London: HM Government. https://www.gov.uk/government/speeches/the-governments-negotiatin g-objectives-for-exiting-the-eu-pm-speech. Accessed 27 January 2021.

Mölling, C. and B. Giegerich, B. 2018. 'The United Kingdom's Contribution to European Security and Defence' DGAP External Publications. 12 February. Berlin: DGAP/German Council on Foreign Relations. https://dgap.org/en/research/publications/united-kingdoms-contribution-european-secur ity-and-defence. Accessed 27 January 2021.

Monar, J. 2010. The EU's Externalisation of Internal Security Objectives: Perspectives after Lisbon and Stockholm. The International Spectator 45 (2): 23-39.

National Crime Agency. 2021. European Arrest Warrants. National Crime Agency, London, UK. https ://nationalcrimeagency.gov.uk/what-we-do/how-we-work/providing-specialist-capabilities-for-lawenforcement/fugitives-and-international-crime/european-arrest-warrants. Accessed 27 January 2021.

NATO. 1949. North Atlantic Treaty Organisation: Atlantic Treaty. 4 April. NATO Publications. https:// www.nato.int/cps/en/natolive/official_texts_17120.htm. Accessed 27 January 2021.

Niblett, R. 2021. 'Global Britain, Global Broker: a blueprint for the UK's future international role', Research Paper, 11 January. https://www.chathamhouse.org/2021/01/global-britain-global-broker. Accessed 27 January 2021.

Nováky, N. 2020. 'The EU's Security and Defence Policy: the impact of the Coronavirus' Research Paper. Brussels: Wilfried Martens Centre for European Studies. https://doi.org/10.1177/17816 85820972246. Accessed 27 January 2021.

Nováky, N. 2018. France's European Intervention Initiative: towards a culture of burden sharing. Policy Brief Brussels: Wilfried Martens Centre for European Studies.

Oliver, T. 2016. European and international views of Brexit. Journal of European Public Policy 23 (9): 1321-1328.

Oltermann, P. and Boffey, D. 2020. 'UK making 'impossible demands' over Europol database in EU talks' Guardian, 23 April. https://www.theguardian.com/world/2020/apr/23/uk-making-impossible -demands-over-europol-database-in-eu-talks. Accessed 27 January 2021.

Pannier, A. 2020. Rivals in Arms: The Rise of UK-France Defence Relations in the Twenty-First Century. London: McGill-Queen's University Press.

Perot, E. 2019. 'The Aachen Mutual Defence Clause: A Closer Look at the Franco-German Treaty' Security Policy Brief 105. February. Brussels: Egmont Institute. https://www.jstor.org/stable/resre p21385?seq=1\#metadata_info_tab_contents. Accessed 27 January 2021.

Quintin, A. 2020. 'Cuts in the European Defence Fund's budget: at what cost?' Global Risk Insights 20 October. https://globalriskinsights.com/2020/10/cuts-in-the-european-defence-funds-budget-atwhat-cost/. Accessed 27 January 2021. 
Reuters. 2020 'Visegrad Four grouping push back on new EU migration plan' Reuters 24 September. https://www.reuters.com/article/us-europe-migrants-hungary/visegrad-four-grouping-push-backon-new-eu-migration-plan-idUSKCN26F1T6. Accessed 27 January 2021.

Richardson, J. and Rittberger, V. 2020. (eds) 'The Brexit Policy Fiasco'. Special Issue, Journal of European Public Policy. 27(5): 649-794.

Ring, S., Du, L., and Morales, A. 2018. 'Hard Brexit risks UK status as 'gateway to Europe' for Japan as companies size up new sites’ The Independent, 7 October. https://www.independent.co.uk/news/ uk/home-news/japan-hard-brexit-uk-trade-toyota-panasonic-muji-nissan-tokyo-gateway-europ e-a8571916.html. Accessed 27 January 2021.

Roberts, C. et al. 2019. 'The UK in the Global Economy', IPPR: https://www.ippr.org/research/publicatio ns/uk-in-the-global-economy. Accessed 27 January 2021.

Sampson, T. 2020. The UK Economy: Brexit vs Covid-19. Commentary. UK in a Changing Europe. King's College London. https://ukandeu.ac.uk/the-uk-economy-brexit-vs-covid-19/. Accessed 27 January 2021.

Schimmelfennig, F. 2018. Brexit: differentiated disintegration in the European Union. Journal of European Public Policy 25 (8): 1154-1173.

Sprenger, S. 2020. 'Germany, France plot new steps for trinational fighter jet, but what about Spain?' Defence News, 6 February. https://www.defensenews.com/global/europe/2020/02/06/germanyfrance-plot-new-steps-for-trinational-fighter-jet-but-what-about-spain/. Accessed 27 January 2021.

Stojanovic, A. 2017. 'Mutual recognition: can the UK have its Brexit cake and eat it?' Institute for Government 1 September. https://www.instituteforgovernment.org.uk/blog/mutual-recognition-can-ukhave-its-brexit-cake-and-eat-it. Accessed 27 January 2021.

Sus, M. 2017. 'The future of European defence depends on the commitment of member states'. Dahrendorf Forum blog, 14 December. https://www.dahrendorf-forum.eu/the-future-of-european-defencedepends-on-the-commitment-of-member-states/. Accessed 27 January 2021.

Taylor, T. 2020. 'Brexit's Implications for UK Defence Industrial Cooperation with Europe'. Commentary Royal United Services Institute. https://www.rusi.org/commentary/brexit-implications-ukdefence-industrial-cooperation-europe. Accessed 27 January 2021.

Tetlow, G. and Pope, T. 2020. 'Brexit and coronavirus: economic impacts and policy response' Insight. December. London: Institute for Government. https:/www.instituteforgovernment.org.uk/sites/ default/files/publications/brexit-coronavirus-economic-impact.pdf. Accessed 27 January 2021.

The Economist. 2021. 'Britain has lost the EU. Can it find a role? 'Global Britain' is a fine idea, but it requires hard choices and re-engagement with Europe', 2 January. London: Economist Newspapers Limited. https:/www.economist.com/leaders/2021/01/02/britain-has-lost-the-eu-can-it-find-a-role. Accessed 27 January 2021.

The Economist. 2020. 'The Special Relationship - A weaker post-Brexit Britain looks to America: good luck with that' Briefing. 30 January. London: Economist Newspapers Ltd. https://www.economist. com/briefing/2020/01/30/a-weaker-post-brexit-britain-looks-to-america. Accessed 27 January 2021.

The Economist. 2018. 'What to Expect from a no-deal Brexit: the terrifying consequences if nothing is sorted' The Economist. Briefing. 24 November. London: Economist Newspapers Ltd. https://www. economist.com/briefing/2018/11/24/what-to-expect-from-a-no-deal-brexit. Accessed 27 January 2021.

The Observer. 2019. ' Something resembling hell' how does the rest of the world view the UK?' The Observer 4 August. London: Guardian Newspapers Limited. https://www.theguardian.com/polit ics/2019/aug/04/how-does-the-rest-of-the-world-currently-view-the-uk-brexit-boris-johnson. Accessed 27 January 2021.

Tocci, N. 2018. 'Towards a European Security and Defence Union: Was 2017 a Watershed?' Journal of Common Market Studies 56 Annual Review: 131-41. DOI: https://doi.org/10.1111/jcms.12752 . Accessed 27 January 2021.

Tonra, B. 2019. 'Brexit and Security', European Journal of Legal Studies 11 (Special Issue): 219-244.

TRT World. 2018 'Spain's Navy wants big role in post-Brexit European defence', 28 April. https:// www.trtworld.com/europe/spain-s-navy-wants-big-role-in-post-brexit-european-defence-17051. Accessed 27 January 2021.

Tusk, D. 2016. 'Speech by President Donald Tusk at the European Policy conference'. Brussels: European Council. 13 October. https://www.consilium.europa.eu/en/press/press-releases/2016/10/13/ tusk-speech-epc/. Accessed 27 January 2021. 
UK Ministry of Defence. 2020. The Integrated Review of Security, Defence, Development and Foreign Policy. 14 September. London: Ministry of Defence. https://www.gov.uk/government/collections/ integrated-review-ministry-of-defence. Accessed 27 January 2021.

UK Ministry of Defence. 2016. 'Defence Secretary welcomes deployable UK-France Joint Force' 21 April. London: HM Government. https://www.gov.uk/government/news/defence-secretary-welco mes-deployable-uk-france-joint-force--2. Accessed 27 January 2021.

UK Ministry of Defence. 2014. 'International partners sign Joint Expeditionary Force agreement' 5 September. London: HM Government. https://www.gov.uk/government/news/international-partnerssign-joint-expeditionary-force-agreement. Accessed 27 January 2021.

UK Ministry of Defence. 2010. 'UK-France Defence Cooperation Treaty Announced'. 2 November. London: HM Government. https://www.gov.uk/government/news/uk-france-defence-co-operation-treat y-announced--2. Accessed 27 January 2021.

UK Parliament. 2019. 'Building bridges - reawakening UK-India ties: trade, investment, and movement of people' 24 June. https://publications.parliament.uk/pa/cm201719/cmselect/cmfaff/2633/2633. pdf. Accessed 27 January 2021.

UK Parliament. 2016. 'Brexit: impact across policy areas' Briefing Paper, 7213. 26 August. House of Commons Library https://commonslibrary.parliament.uk/research-briefings/cbp-7213/. Accessed 27 January 2021.

van Raybroeck, R. 2019. 'What's in the CARDs?' 103 February 1-7. Security Policy Brief Brussels: Egmont Institute. http://www.egmontinstitute.be/whats-in-the-cards/. Accessed 27 January 2021.

Wall, D. S. 2016. 'Policing cybercrime in the EU: Shall I stay, or shall I go?' British Society of Criminology Newsletter 1 (Summer).

Wilkinson, B. 2020. 'The EU's Defence, Technological and Industrial Base' in 10 Years of CSDP: Four in-depth analyses requested by the sub-committee on Security and Defence of the European Parliament. Brussels: European Parliament. https://www.europarl.europa.eu/RegData/etudes/ IDAN/2020/603485/EXPO_IDA(2020)603485_EN.pdf. Accessed 27 January 2021.

Witney, N. 2017. 'EU defence efforts miss the open goal again' Commentary 15 November https://www. ecfr.eu/article/commentary_eu_defence_efforts_miss_the_open_goal_again. Accessed 27 January 2021.

Yu, J. 2017. After Brexit: Risks and Opportunities to EU-China Relations. Global Policy 8 (4): 109-114.

Zalan, E. 2016. 'EU migrant quota idea is finished, Fico says' EUObserver, 27 September. https://euobs erver.com/migration/135245. Accessed 27 January 2021.

Publisher's Note Springer Nature remains neutral with regard to jurisdictional claims in published maps and institutional affiliations.

Dr Simon Sweeney is a Senior Lecturer in International Political Economy in York Management School, at the University of York. His research and published work explore EU Common Security and Defence Policy, EU global strategy, and the European Union's role in the Western Balkans.

Dr Neil Winn is a Senior Lecturer in European Studies in the School of Politics and International Studies, at the University of Leeds. His research covers European integration, common foreign and security policy and common security and defence policy. He has published widely on international relations, EU global strategy, conflict resolution, and EU common foreign and security policy. 